\title{
MEDIA PEMBELAJARAN PENGENALAN PERANGKAT KERAS KOMPUTER MENGGUNAKAN AUGMENTED REALITY
}

\author{
Robby Yuli Endra ${ }^{\# 1}$, Dian Resha Agustina*2 \\ Program Studi Informatika, Fakultas Ilmu Komputer Universitas Bandar Lampung \\ Jalan Zainal Abidin Pagar Alam No 89, Bandar Lampung, Indonesia \\ ${ }^{1}$ robby $y u l i e n d r a a u b l \cdot a c \cdot$ id \\ ${ }^{2}$ dian.reshalubl.ac.id
}

\begin{abstract}
Abstrak
Tujuan dari penelitian ini diarahkan untuk menambah referensi belajar mahasiswa Pengantar Teknologi Informasi dan Komunikasi di lingkungan Fakultas Ilmu Komputer Universitas Bandar Lampung, dengan memungkinkan penggunanya melihat komponen perangkat keras komputer beserta detailnya. Sejauh ini pada materi pengenalan perangkat keras komputer media belajar mahasiswa umumnya langsung melihat komponen komputer di kelas saat matakuliah berlangsung. Penelitian ini merancang sebuah aplikasi pembelajaran pengenalan perangkat keras komputer, dimana desain penanda/marker yang telah disediakan oleh peneliti. Pengguna dapat melihat Komponen-komponen perangkat keras komputer dapat dilihat dalam bentuk objek virtual, yang diarahkan pada marker. Pada penelitian ini, peneliti menggunakan metode markerless augmented reality dimana marker yang digunakan sebagai tracker tidak hanya gambar hitam dan putih serta berbentuk garis yang tegas pada Sisi-sisi marker. Sehingga pada penelitian ini, marker yang digunakan oleh peneliti dibuat berdasarkan gambar 3 dimensi dari objek yang akan tampil langsung
\end{abstract}

Kata Kunci : augmented reality, markerless, marker, android

\section{Pendahuluan}

Teknologi image processing dan computer vision telah berkembang ke tahap yang memungkinkan kita untuk menciptakan informasi 3D pada dunia nyata melalui gambar. Karena keberhasilan teknologi ini, segala bidang berbasis aplikasi Augemented Reality muncul. Augmented reality sebagai kombinasi antara dunia nyata dan dunia maya dalam 3D dengan kemampuan interaksi dengan waktu yang nyata. Salah satu penerapan bidang Augmented Reality adalah membangun aplikasi pengenalan objek-objek menggunakan sebuah marker. Pada aplikasi ini diharapkan bermanfaat bagi pengguna untuk dapat mengenali beberapa perangkat keras yang ada pada komputer melalui representasi visual 3 dimensi dengan melibatkan interaksi user. untuk mengimplementasikan augmented reality tidak memerlukan peralatan dengan biaya yang tinggi, maka mahasiswa dan pengguna umum diharapkan mudah menggunakan aplikasi ini. (R. Y. Endra, 2017)

Augmented reality adalah teknologi yang saat ini masih sangat baru dalam bidang computer vision. Teknik dasar augmented reality terbentuk pada 1960-an, dan sekarang augmented reality menjadi benar-benar praktis untuk digunakan diberbagai bidang. Kemajuan baru dalam pengolahan mobile, ditambah dengan kapasitas penyimpanan digital, kemajuan spesifikasi smartphone, dan penyimpanan data tak terbatas pada internet telah mengumpulkan semua prasyarat untuk membangun potensi teknologi augmented reality ini. Aplikasi augmented

reality sudah hadir pada ratusan juta ponsel pintar dengan memanfaatkan built-in camera, accelerometers, mikrofon, Global Positioning System (GPS), dan dengan perkembangan augmented reality ini perusahaan chip besar seperti Nvidia dan Qualcomm, AR price-point, dll akan mengembangkan aplikasi augmented reality lebih lanjut. Kesimpulannya Augmented Reality diciptakan untuk mendukung produk dan layanan industri media sebagai teknologi.

Markerless Augmented reality adalah metode dimana pengguna tidak perlu lagi menggunakan sebuah marker/penanda yang berbentuk kotak dan berwarna hitam putih untuk menampilkan elemenelemen digital. Hal ini tentu membantu instansi/perusahaan untuk membuat kreasi grafis pada maker agar terlihat lebih menarik bagi para penggunanya. Aplikasi yang akan dikembangkan oleh peneliti adalah sebuah aplikasi yang berbasis augmented reality. Aplikasi berupa pengembangan media belajar komputer untuk pengenalan perangkat keras yang ada pada komputer berbasis android untuk pembelajaran dan pengenalan terhadap mahasiswa dengan tampilan objek model 3 dimensi. Sedangkan untuk masukan gambar pengguna dapat menggunakan android dengan marker yang telah disediakan pada kertas. Dalam kertas tersebut berisi marker dengan gambar grafis beraneka ragam untuk 
setiap perangkat keras dalam komputer yang diidentifikasi menggunakan kamera smartphone untuk menampilkan sebuah objek 3 dimensi.

Sejauh ini, kegiatan belajar pengenalan perangkat keras komputer di kelas sudah cukup baik untuk dipahami oleh mahasiswa. Namun akan lebih baik jika kegiatan belajar pengenalan perangkat keras ini di kemas menjadi suatu media menarik untuk menambah minat mahasiswa dalam mempelajarinya dimana saja dan kapan saja secara fleksibel pada smartphone. Dalam hal ini peran seorang dosen sebagai pengembang ilmu sangat besar untuk memilih dan melaksanakan pembelajaran yang tepat dan efesien bagi peserta didik.

Fakultas ilmu komputer merupakan salah satu Fakultas yang ada di Universitas Bandar Lampung yang terdiri dari program studi Sistem Informasi dan Teknik Informatika. Pada Program Studi Teknik Informatika dan Sistem Informasi semester 1 (satu) terdapat matakuliah Pengantar Teknologi Informasi dan Komunikasi (PTIK) yang mempelajari perangkat keras komputer. Matakuliah PTIK mempelajari tentang hardware, software, brainware, akumulasi data, informasi dan pengetahuan komputer dalam 3 SKS. Umumnya matakuliah ini masih menggunakan metode kegiatan belajar dengan penyampian ceramah plus dikelas. Hal ini membuat peneliti ingin menciptakan aplikasi media pembelajaran mengenal perangkat keras komputer meliputi Random Acces Memory (RAM), processor, hardisk, VGA, CD-ROM, LAN card, sound card, fan, power supply, casing, serta perangkat dalam motherboard yang ditampilkan dengan detail spesifikasinya menggunakan teknologi augmented reality pada marker yang tersedia.

\subsection{Identifikasi masalah}

Berdasarkan Pendahululan pada poin 1 diatas dapat diidentifikasi masalah sebagai berikut :

a. Kurang memahami dan mengenalnya mahasiswa terhadap komponen perangkat keras komputer.

b. Belum adanya media pembelajaran interaktif yang dapat digunakan untuk mengenali perangkat keras komputer.

\subsection{Rumusan masalah}

Rumusan masalah pada penelitian ini adalah :

Bagaimana Membuat media pembelajaran dengan teknologi augmented reality pada mata kuliah pengenalan perangkat keras komputer pada matakuliah Pengantar Teknologi Informasi dan Komunikasi (PTIK) dilingkungan Fakultas Ilmu Komputer Universitas Bandar Lampung

\subsection{Tujuan dan Manfaat Penelitian}

Adapun tujuan yang ingin dicapai peneliti ialah :

a. Meningkatkan pemahaman mahasiswa terhadap komponen perangkat keras komputer.

b. Pengguna dapat menggunakan aplikasi pembelajaran secara fleksibel kapan saja menggunakan smartphone dan menggunakan marker.

c. Implementasi augmented reality pada media pembelajaran pengenalan perangkat keras komputer untuk menambah referensi belajar mahasiswa.

Adapun manfaat yang ingin dihasilkan peneliti ialah

a. Memudahkan mahasiswa untuk menggunakan media belajar dimanapun dan kapan saja menggunakan smartphone.

b. Dapat memperjelas objek yang kecil menjadi besar, dan objek besar dapat diperkenalkan dengan tampilan objek yang diperkecil yang dibuat melalui virtual 3 dimensi.

\section{Penelitian Terkait dan Landasan Teori}

\subsection{Penelitian Terkait}

Pada penelitian yang berjudul 3d Outdoor Augmented Reality For Architecture And Urban Planning yang dilakukan oleh Arnis Cirulisa, Kristaps Brigis, dan Brigmanis menjelaskan bahwa Marker augmented reality digunakan khusus untuk pelacakan dan posisi dengan 3 dimensi. Marker digunakan untuk mengidentifikasi objek virtual yang sesuai yang akan ditempatkan di lingkungan dunia nyata. Saat marker digunakan sebagai target pelacakan, maka konten harus didaftarkan ke database sistem sebelumnya, lengkap dengan bendabenda maya yang dikaitkan. Namun, markers yang digunakan dalam satu sistem tidak dapat diterapkan dalam sistem lain karna informasi bersifat khusus. Markerless digunakan untuk melacak yang bergantung pada konten alami yang terlihat dalam lingkungan pengguna. Empat syarat dikemukaan oleh Herling dan Broll, untuk meningkatkan keakuratan maka ditimbulkan penentuan dari titik alami (waktu perhitungan cepat, ketahanan terhadap perubahan kondisi pencahayaan dan gambar kabur, ketahanan terhadap pengamatan dari sudut pandang yang berbeda, skala bebas atau mengubah jarak penglihatan). (K, 2013)

Penelitian lain yang berjudul Pemanfaatan Augmented Reality Sebagai Media Informasi Kampus Menggunakan Brosur yang diteliti oleh Latius Hermawan dan Mochamad Hariadi menjelaskan bahwa Salah satu komponen penting yang harus ada untuk mendukung kinerja dari proses pengolahan citra digital (Augmented Reality) yaitu tracking yang melakukan pendeteksian dan melacak objek dunia nyata yang ada pada vidio kamera dengan algoritma yang berbeda bertugas untuk mendeteksi trackable baru, dan mengevaluasi virtual button. Hasilnya akan disimpan dalam state objek yang akan digunakan oleh video background renderer dan dapat diakses dari application codes. Aplikasi yang akan dibuat menggunakan Android, dalam penerapannya dibuat marker dengan pola yang telah ditentukan dimana akan diidentifikasi koordinatnya sehingga akan menampilkan objek 
gedung, pohon, teks 3 dimensi yang telah dibuat. Pengguna dapat mengarahkan kamera keatas brosur sebagai penanda dan aplikasi akan melakukan tracking ke database untuk mencari objek yang sesuai dengan penanda yang didapatkan untuk ditampilkan ke layar. Apabila brosur penanda dan gambar yang ada didalam database sesuai, maka kamera akan melakukan proses render untuk mengakses objek. Selanjutnya aplikasi akan menampilkan konten informasi augmented reality sesuai dengan gambar yang ada pada brosur. (Hariadi, 2015)

Penelitian lain yang dilakukan oleh Debora M. Lengkey, Yaulie D. Y. Rindengan, ST., MSc., MM., dan Virginia Tulenan, S.Kom yang berjudul "Brosur Fakultas Teknik Universitas Sam Ratulangi Manado Dengan Teknologi Markerless Augmented Reality" Dengan brosur yang menerapkan teknologi Augmented reality, informasi yang tidak dapat diterima oleh pengguna dengan inderanya sendiri dapat ditampilkan dengan Benda-benda maya. Hal ini membuat augmented reality sesuai sebagai alat untuk membantu persepsi dan interaksi penggunanya dengan dunia nyata. Informasi yang ditampilkan oleh benda maya membantu pengguna melaksanakan kegiatan dalam dunia nyata. Teknik display augmented reality merupakan sistem manipulasi citra yang menggunakan seperangkat optik, elektronik, dan komponen mekanik untuk membentuk citra dalam jalur optik antara mata pengamat dan objek fisik yang akan digabungkan dengan teknik augmented reality. Bergantung kepada optik yang digunakan, citra bisa dibentuk pada sebuah benda datar atau suatu bentuk permukaan yang kompleks (tidak datar). Brosur yang dijadikan media informasi dan promosi dengan menggunakan sistem manipulasi objek nyata dan animasi ini memberikan tampilan yang lebih nyata dan menarik kepada masyarakat luas dalam yang atraktif. (D. M. Lengkey, 2014)

\subsection{Landasan Teori}

\subsubsection{Augmented Reality}

Augmented Reality adalah variasi dari Virtual Environtment (VE), atau atau biasa disebut dengan Virtual Reality (VR). Teknologi Virtual Reality benar-benar membenamkan pengguna dalam lingkungan buatan, pengguna tidak dapat melihat dunia nyata di sekelilingnya. Sebaliknya, Augmented Reality mengambil informasi digital atau komputer yang dihasilkan, apakah itu gambar, audio, video, dan sentuhan yang melapisi mereka selama di lingkungan real-time. Teknik Augmented Reality dapat digunakan untuk meningkatkan semua panca indera, tetapi yang paling umum digunakan saat ini adalah visual. Tidak seperti Virtual Reality, Augmented Reality memungkinkan pengguna untuk melihat dunia nyata, dengan objek virtual ditumpangkan atau digabungkan dengan dunia nyata. Oleh karena itu, Augmented Reality merupakan tambahan kenyataannya, daripada benar-benar menggantinya. Augmented Reality dapat dianggap sebagai campuran, atau "jalan tengah," antara yang benar-benar buatan dan yang benar-benar nyata. (J, 2014)

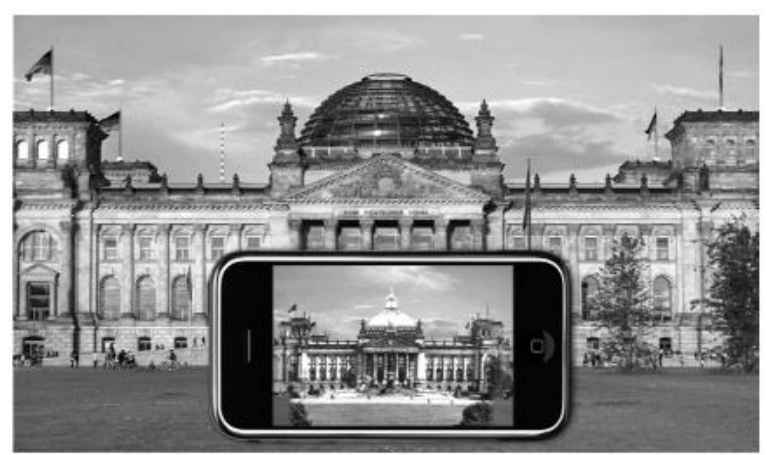

Gambar 1. Reality menggunakan Smartphone

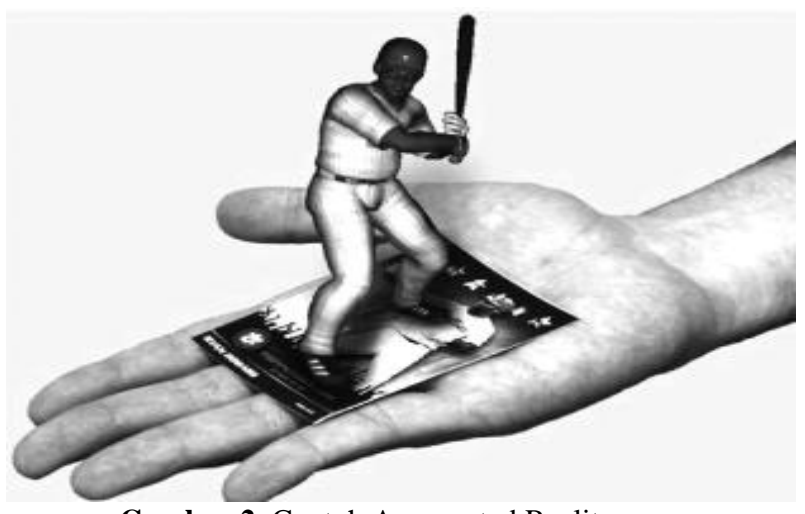

Gambar 2. Contoh Augmented Reality

\subsubsection{Media Pembelajaran}

media pembelajaran adalah segala sesuatu yang dapat digunakan untuk menyalurkan pesan (bahan pembelajaran), sehingga dapat merangsang perhatian, minat, pikiran, dan perasaan mahasiswa dalam kegiatan belajar untuk mencapai tujuan belajar. (Daryanto, 2013)

\section{Metode Penelitian}

Metode penelitian pada dasarnya merupakan cara ilmiah untuk mendapatkan data dengan tujuan dan kegunaan tertentu. Berdasarkan hal tersebut terdapat empat kata kunci yang perlu diperhatikan, yaitu, cara ilmiah, data, tujuan dan kegunaan. Cara ilmiah berarti kegiatan penelitian itu didasarkan pada Ciriciri keilmuan yaitu, rasional, empiris, dan sistematis. Rasional berarti kegiatan penelitian itu dilakukan dengan Cara-cara yang masuk akal, sehingga terjangkau oleh penalaran manusia. Empiris berarti Cara-cara yang dilakukan itu dapat diamati oleh indera manusia, sehingga orang lain dapat mengamati dan mengetahui Cara-cara yang digunakan. Sistematis artinya, proses yang digunakan dalam penelitian itu menggunakan Langkah-langkah tertentu yang bersifat logis. (Sugiyono, 2014) 


\section{Hasil dan Pembahasan Penelitian 4.1. Pembahasan}

\subsubsection{Proses Pembuatan Objek 3 Dimensi}

Pada penelitian ini, peneliti menggunakan software pengolah animasi 3DS Max. Software ini digunakan untuk mengolah dan membuat objek 3 Dimensi dari Komponen-komponen komputer yang akan dijadikan sebagai acuan belajar pengguna. software yang digunakan peneliti adalah versi Autodesk $3 d s$ Max 9 32-bit. Tahap-tahap yang dilakukan oleh peneliti yaitu :

a. Membuat Objek Single

Untuk membuat objek single yang diambil langsung dari menu yang tersedia pada 3DS Max kita dapat membuatnya dengan mengklik dahulu button "Box" yang tersedia pada Geometry - Object Type - Box. Lalu drag ukuran panjang $\mathrm{x}$ lebar sesuai yang anda inginkan, setelah itu anda drag kembali untuk ukuran tinggi box tersebut.

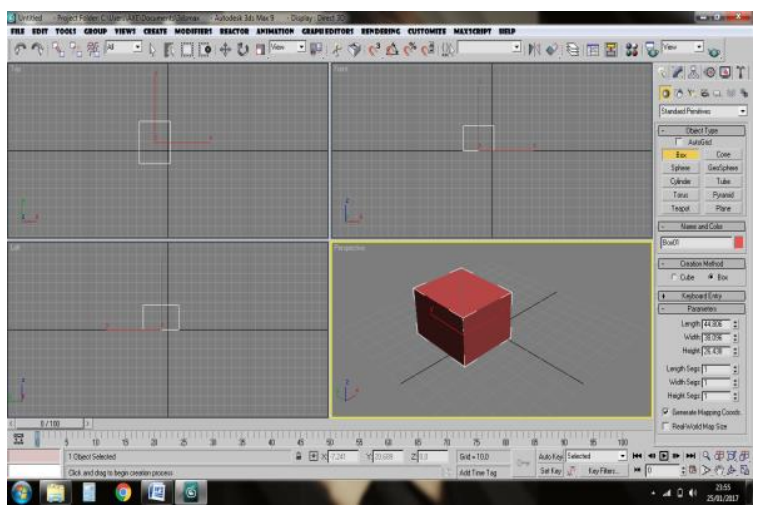

Gambar 3. Objek single

b. Mengkonvert Objek

Mengkonvert objek dilakukan agar objek single tersebut dapat fleksibel atau dengan mudah kita edit bentuknya. Caranya dengan mengklik kanan objek convert to : - convert to editable poly.

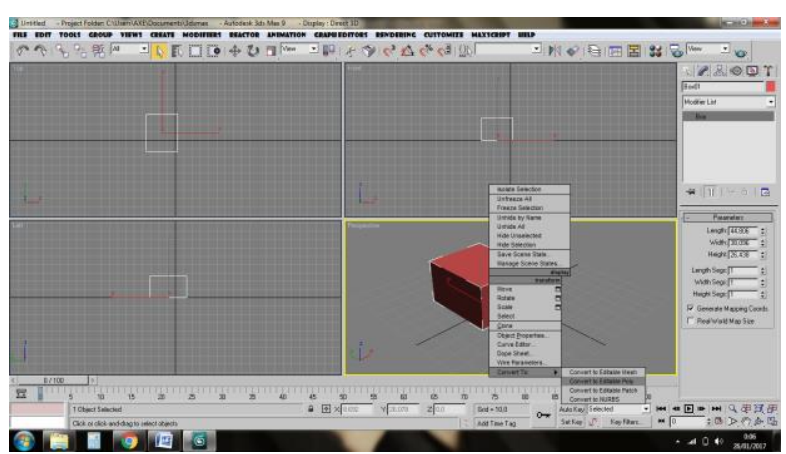

Gambar 4. Mengkonvert objek

\subsubsection{Membuat Objek pada Marker sebagai} Tracker

Asset vuforia unity package serta sdk for android yang telah disediakan di vuforia di import ke unity. fungsinya adalah, vuforia unity package untuk mengambil AR camera dan image target pada unity. sedangkan sdk manager android adalah untuk build aplikasi yang sudah selesai dirancang pada unity.

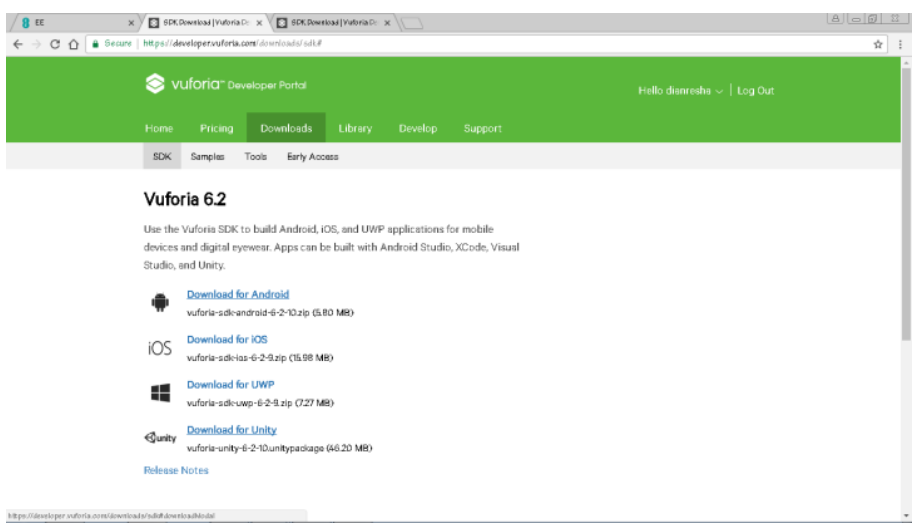

Gambar 5. Mengambil vuforia unity package

\subsubsection{Menggabungkan Marker dan Objek 3} Dimensi

Komponen komputer yang di Objek 3D di import ke unity, dan marker yang telah diunduh dari database vuforia di import ke unity dengan mengatur scale sesuai dengan marker yang akan ditampilkan.

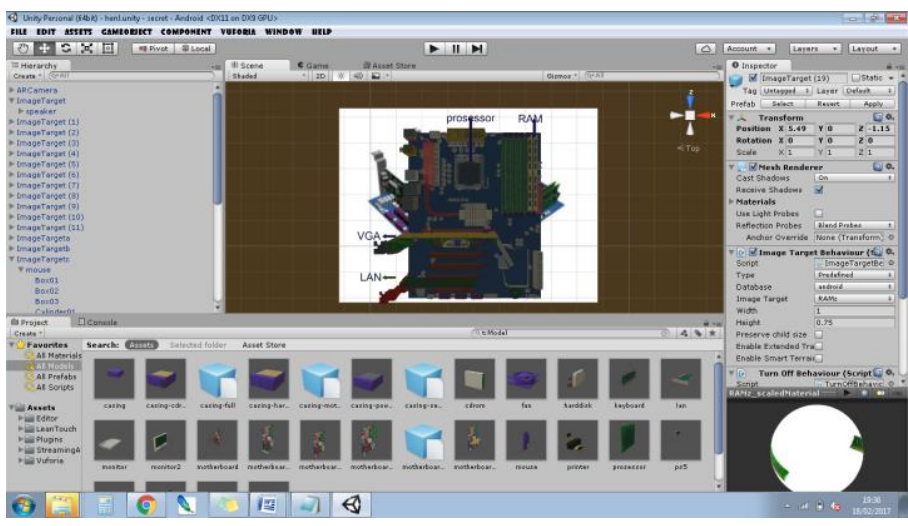

Gambar 6. Membuat aplikasi AR dengan unity

\subsection{Hasil Penelitian}

\subsubsection{Desain Interface}

Aplikasi yang telah dijalankan di android akan menampilkan berbagai macam objek 3D komponen komputer yang ditampilkan sesuai marker yang terdeteksi sebagai berikut :

\section{Monitor}

Berikut ini adalah tampilan gambar visual 3 Dimensi yang terdeteksi dari marker bergambar monitor. 


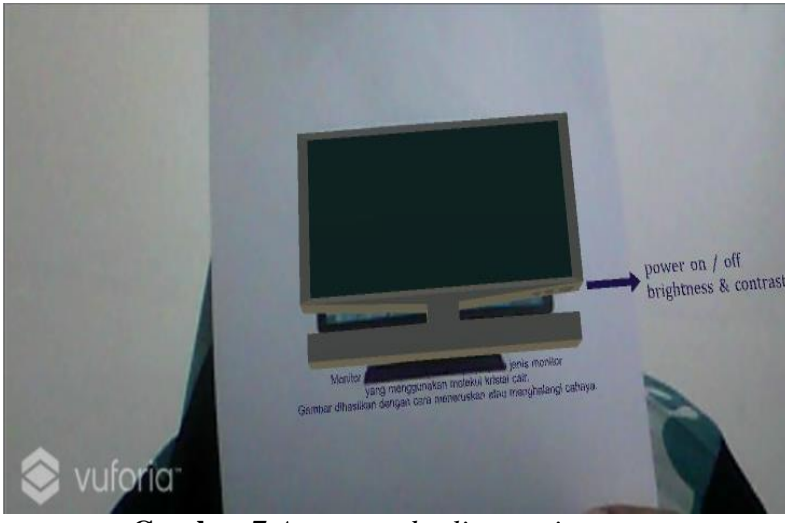

Gambar 7 Augmented relity monitor

\subsubsection{Penggabungan Marker Motherboard} dan VGA Card

Berikut ini adalah tampilan gambar visual 3 Dimensi yang terdeteksi dari marker bergambar casing dan marker bergambar VGA card.

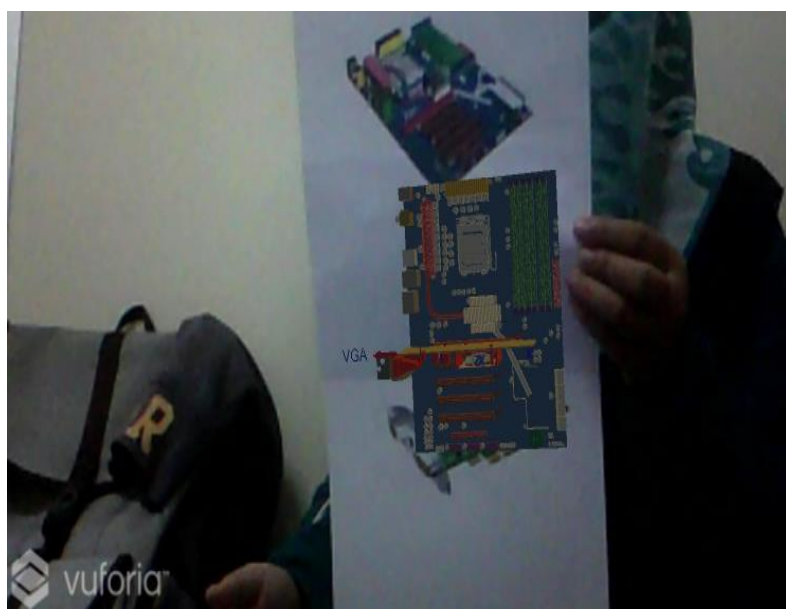

Gambar 8. Augmented relity motherboard dan VGA card

\subsubsection{Pengujian Aplikasi}

\section{a. Black box Testing}

Terfokus pada apakah unit program memenuhi kebutuhan (requirement) yang disebutkan dalam spesifikasi. Pada black box testing, cara pengujiannya hanya dilakukan dengan menjalankan atau mengeksekusi unit atau modul, kemudian diamati apakah hasil dari unit itu sesuai dengan proses bisnis yang diinginkan. Jika ada unit yang tidak sesuai outputnya maka untuk menyelesaikannya dteruskan pada penguian yang kedua, yaitu white box testing.
Tabel 1. Black Box Testing aplikasi pembelajaran komponen komputer

\begin{tabular}{|c|c|c|c|}
\hline No & & Dbjek Yang Diuji & $\begin{array}{c}\text { Hasil } \\
\text { Penguj } \\
\text { ian }\end{array}$ \\
\hline 1 & $\begin{array}{l}\text { Input } \\
\text { Action } \\
\text { Result }\end{array}$ & $\begin{array}{l}\text { : Kamera AR aktif } \\
\text { : Deteksi marker casing } \\
\text { : Tampil objek virtual casing }\end{array}$ & Sesuai \\
\hline 2 & $\begin{array}{l}\text { Input } \\
\text { Action } \\
\text { Result }\end{array}$ & $\begin{array}{l}\text { : Kamera AR aktif } \\
\text { : Deteksi marker CD-ROM } \\
\text { : Tampil objek virtual CD- } \\
\text { ROM }\end{array}$ & Sesuai \\
\hline 3 & $\begin{array}{l}\text { Input } \\
\text { Action } \\
\text { Result }\end{array}$ & $\begin{array}{l}\text { : Kamera AR aktif } \\
: \text { Deteksi marker monitor } \\
: \text { Tampil objek virtual monitor }\end{array}$ & Sesuai \\
\hline 4 & $\begin{array}{l}\text { Input } \\
\text { Action } \\
\text { Result }\end{array}$ & $\begin{array}{l}\text { : Kamera AR aktif } \\
\text { : Deteksi marker fan } \\
\text { : Tampil objek virtual fan }\end{array}$ & Sesuai \\
\hline 5 & $\begin{array}{l}\text { Input } \\
\text { Action } \\
\text { Result }\end{array}$ & $\begin{array}{l}\text { : Kamera AR aktif } \\
\text { : Deteksi marker hard disk } \\
\text { : Tampil objek virtual hard } \\
\text { disk }\end{array}$ & Sesuai \\
\hline 6 & $\begin{array}{l}\text { Input } \\
\text { Action } \\
\text { Result }\end{array}$ & $\begin{array}{l}\text { : Kamera AR aktif } \\
\text { : Deteksi marker keyboard } \\
\text { : Tampil objek virtual } \\
\text { keyboard }\end{array}$ & Sesuai \\
\hline 7 & $\begin{array}{l}\text { Input } \\
\text { Action } \\
\text { Result }\end{array}$ & $\begin{array}{l}\text { : Kamera AR aktif } \\
\text { : Deteksi marker LAN card } \\
\text { : Tampil objek virtual Lan } \\
\text { Card }\end{array}$ & Sesuai \\
\hline 8 & $\begin{array}{l}\text { Input } \\
\text { Action } \\
\text { Result }\end{array}$ & $\begin{array}{l}\text { : Kamera AR aktif } \\
\text { : Deteksi marker } \\
\text { motherboard } \\
\text { : Tampil objek virtual } \\
\text { motherboard }\end{array}$ & Sesuai \\
\hline 9 & $\begin{array}{l}\text { Input } \\
\text { Action } \\
\text { Result }\end{array}$ & $\begin{array}{l}\text { : Kamera AR aktif } \\
\text { : Deteksi marker mouse } \\
\text { : Tampil objek virtual mouse }\end{array}$ & Sesuai \\
\hline 10 & $\begin{array}{l}\text { Input } \\
\text { Action } \\
\text { Result }\end{array}$ & $\begin{array}{l}\text { : Kamera AR aktif } \\
: \text { Deteksi marker power } \\
\text { supply } \\
: \text { Tampil objek virtual power } \\
\text { supply }\end{array}$ & Sesuai \\
\hline 11 & $\begin{array}{l}\text { Input } \\
\text { Action } \\
\text { Result }\end{array}$ & $\begin{array}{l}\text { : Kamera AR aktif } \\
\text { : Deteksi marker printer } \\
\text { : Tampil objek virtual printer }\end{array}$ & Sesuai \\
\hline 12 & $\begin{array}{l}\text { Input } \\
\text { Action } \\
\text { Result }\end{array}$ & $\begin{array}{l}\text { : Kamera AR aktif } \\
: \text { Deteksi marker RAM card } \\
: \text { Tampil objek virtual RAM } \\
\text { card }\end{array}$ & Sesuai \\
\hline
\end{tabular}




\begin{tabular}{|c|c|c|c|}
\hline No & & Objek Yang Diuji & $\begin{array}{c}\text { Hasil } \\
\text { Penguj } \\
\text { ian }\end{array}$ \\
\hline 13 & $\begin{array}{l}\text { Input } \\
\text { Action } \\
\text { Result }\end{array}$ & $\begin{array}{l}\text { : Kamera AR aktif } \\
\text { : Deteksi marker processor } \\
\text { : Tampil objek virtual } \\
\text { processor }\end{array}$ & Sesuai \\
\hline 14 & $\begin{array}{l}\text { Input } \\
\text { Action } \\
\text { Result }\end{array}$ & $\begin{array}{l}\text { : Kamera AR aktif } \\
: \text { Deteksi marker sound card } \\
: \text { Tampil objek virtual sound } \\
\text { card }\end{array}$ & Sesuai \\
\hline 15 & $\begin{array}{l}\text { Input } \\
\text { Action } \\
\text { Result }\end{array}$ & $\begin{array}{l}\text { : Kamera AR aktif } \\
\text { : Deteksi marker speaker } \\
\text { : Tampil objek virtual } \\
\text { speaker }\end{array}$ & Sesuai \\
\hline 16 & $\begin{array}{l}\text { Input } \\
\text { Action } \\
\text { Result }\end{array}$ & $\begin{array}{l}\text { : Kamera AR aktif } \\
\text { : Deteksi marker komponen } \\
\text { dalam casing } \\
\text { : Tampil objek virtual } \\
\text { komponen dalam casing }\end{array}$ & Sesuai \\
\hline 17 & $\begin{array}{l}\text { Input } \\
\text { Action } \\
\text { Result }\end{array}$ & $\begin{array}{l}\text { : Kamera AR aktif } \\
: \text { Deteksi marker casing dan } \\
C D-R O M \\
: \text { Tampil objek virtual casing } \\
\text { dan CD-ROM }\end{array}$ & Sesuai \\
\hline 18 & $\begin{array}{l}\text { Input } \\
\text { Action } \\
\text { Result }\end{array}$ & $\begin{array}{l}\text { : Kamera AR aktif } \\
\text { : Deteksi marker casing dan } \\
\text { power supply } \\
\text { : Tampil objek virtual casing } \\
\text { dan power supply }\end{array}$ & Sesuai \\
\hline 19 & $\begin{array}{l}\text { Input } \\
\text { Action } \\
\text { Result }\end{array}$ & $\begin{array}{l}\text { : Kamera AR aktif } \\
\text { : Deteksi marker casing dan } \\
\text { hard disk } \\
\text { : Tampil objek virtual casing } \\
\text { dan hard disk }\end{array}$ & Sesuai \\
\hline 20 & $\begin{array}{l}\text { Input } \\
\text { Action } \\
\text { Result }\end{array}$ & $\begin{array}{l}\text { : Kamera AR aktif } \\
: \text { Deteksi marker casing dan } \\
\text { motherboard } \\
: \text { Tampil objek virtual casing } \\
\text { dan motherboard }\end{array}$ & Sesuai \\
\hline 21 & $\begin{array}{l}\text { Input } \\
\text { Action } \\
\text { Result }\end{array}$ & $\begin{array}{l}\text { : Kamera AR aktif } \\
: \text { Deteksi marker seluruh } \\
\text { komponen motherboard } \\
: \text { Tampil objek virtual seluruh } \\
\text { komponen motherboard }\end{array}$ & Sesuai \\
\hline 22 & $\begin{array}{l}\text { Input } \\
\text { Action } \\
\text { Result }\end{array}$ & $\begin{array}{l}\text { : Kamera AR aktif } \\
\text { : Deteksi marker } \\
\text { motherboard dan LAN card } \\
: \text { Tampil objek virtual } \\
\text { motherboard dan LAN card }\end{array}$ & Sesuai \\
\hline 23 & $\begin{array}{l}\text { Input } \\
\text { Action } \\
\text { Result }\end{array}$ & $\begin{array}{l}\text { : Kamera AR aktif } \\
: \text { Deteksi marker } \\
\text { motherboard dan sound card } \\
: \text { Tampil objek virtual } \\
\text { motherboard dan sound card }\end{array}$ & Sesuai \\
\hline 24 & $\begin{array}{l}\text { Input } \\
\text { Action } \\
\text { Result }\end{array}$ & $\begin{array}{l}\text { : Kamera AR aktif } \\
: \text { Deteksi marker } \\
\text { motherboard dan VGA card } \\
\text { : Tampil objek virtual } \\
\text { motherboard dan VGA card }\end{array}$ & Sesuai \\
\hline
\end{tabular}

\begin{tabular}{|c|c|c|c|}
\hline No & & Objek Yang Diuji & $\begin{array}{l}\text { Hasil } \\
\text { Penguj } \\
\text { ian }\end{array}$ \\
\hline 25 & $\begin{array}{l}\text { Input } \\
\text { Action } \\
\text { Result }\end{array}$ & $\begin{array}{l}\text { : Kamera AR aktif } \\
: \text { Deteksi marker } \\
\text { motherboard dan RAM card } \\
: \text { Tampil objek virtual } \\
\text { motherboard dan RAM card }\end{array}$ & Sesuai \\
\hline 26 & $\begin{array}{l}\text { Input } \\
\text { Action } \\
\text { Result }\end{array}$ & $\begin{array}{l}\text { : Kamera AR aktif } \\
\text { : Deteksi marker } \\
\text { motherboard dan processor } \\
: \text { Tampil objek virtual } \\
\text { motherboard dan processor }\end{array}$ & Sesuai \\
\hline 27 & $\begin{array}{l}\text { Input } \\
\text { Action } \\
\text { Result }\end{array}$ & $\begin{array}{l}\text { : Kamera AR aktif } \\
\text { : Deteksi marker kabel pada } \\
\text { komputer } \\
\text { : Tampil objek virtual kabel } \\
\text { pada komputer }\end{array}$ & Sesuai \\
\hline 28 & $\begin{array}{l}\text { Input } \\
\text { Action } \\
\text { Result }\end{array}$ & $\begin{array}{l}\text { : Kamera AR aktif } \\
\text { : Deteksi marker kabel } \\
\text { dalam casing } \\
: \text { Tampil objek virtual kabel } \\
\text { dalam casing }\end{array}$ & Sesuai \\
\hline
\end{tabular}

\section{b. White Box Testing}

White box testing adalah cara pengujian dengan melihat kedalam modul untuk meneliti Kode-kode program yang ada, dan menganalisis apakah ada kesalahan atau tidak. Jikmenghasilkan output ada modul yang tidak sesuai dengan proses bisnis yang dilakukan, maka Baris-baris program, variabel dan parameter yang terlibat pada unit tersebut akan dicek satu persatu dan diperbaiki, kemudian dicompile ulang. Aplikasi yang telah dibuat diuji kedalam white box testing sebagai berikut :

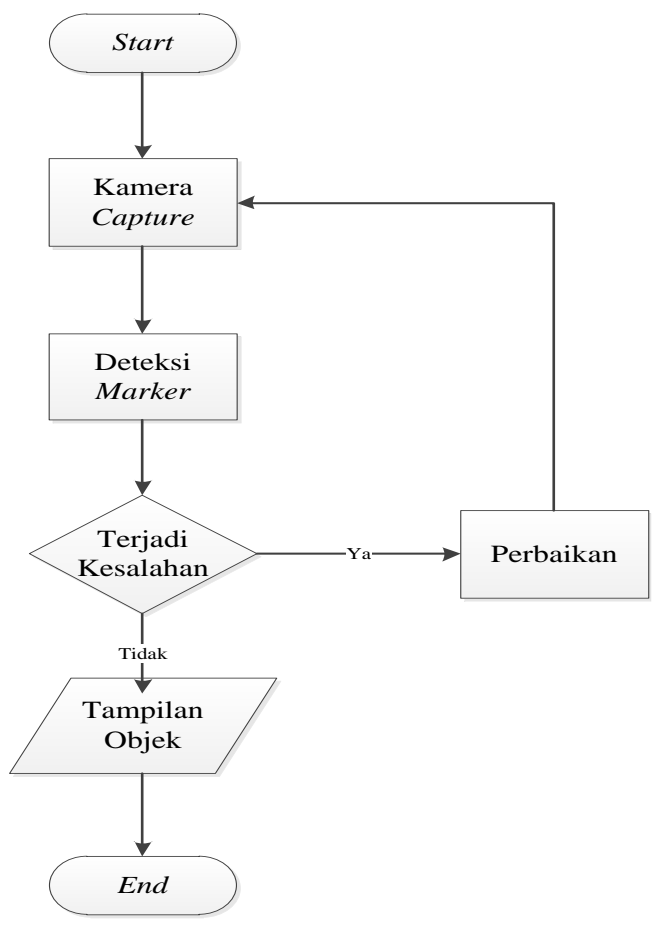

Diagram 9. Flowchart pengujian white box pada aplikasi 


\section{Kesimpulan dan Saran}

\subsection{Kesimpulan}

Berdasarkan hasil penelitian dan pembahasan, maka kesimpulan yang dapat diambil dari penelitian ini adalah sebagai berikut :

a. Dari hasil perancangan yang telah dirancang maka dapat disimpulkan dengan adanya aplikasi pembelajaran ini dapat meningkatkan pemahaman mahasiswa mengenal komponen perangkat keras komputer.

b. Aplikasi pembelajaran komponen perangkat keras komputer dapat diimplementasikan pada matakuliah PTIK Fakultas Ilmu Komputer menggunakan smartphone mahasiswa serta marker yang telah tersedia.

c. Kelemahan dari aplikasi ini yaitu, objek virtual yang tampil di android tidak dapat diputar sesuai rotasi yang diinginkan dan penggunaan kombinasi dua marker masih belum akurat terdeteksi oleh vuforia pada android.

\subsection{Saran}

Saran peneliti untuk pengembangan aplikasi pembelajaran pengenalan komponen perangkat keras komputer dengan augmented reality, yaitu :

a. Mengkoneksikan marker dengan mengambil objek virtual yang sudah disimpan pada database augmented reality.

b. Pada pembuatan animasi komponen perangkat keras komputer objek 3 dimensi dikombinasikan menjadi sebuah alur pemasangan Konektorkonektor yang terhubung pada komponen komputer.

\section{Daftar Pustaka}

D. M. Lengkey, M. Y. (2014). TulenanBrosur fakultas teknik universitas sam ratulangi manado dengan teknologi markerless augmented reality. e-journal Tek. Elektro dan Komputer.

Daryanto. (2013). Media Pembelajaran Peranannya Sangat Penting dalam Mencapai Tujuan Pembelajaran. Yogyakarta: Gava Media.

Hariadi, L. H. (2015). Pemanfaatan Augmented reality Sebagai Media Informasi Kampus Menggunakan Brosur. J. Rekayasa Elektr., vol. 10 .

J, K. G. (2014). Augmented Reality an Emerging Technologies Guide to AR. USA: Elseiver.

K, C. A. (2013). 3D Outdoor Augmented reality for Architecture and Urban Planning. Procedia Comput. Sci: 2013.

R. Y. Endra, D. R. (2017). Positioning Manipulate Real Property Object On Tourist Attraction Utilize Augmented Reality. in The 4th International Conference on Engineering and Technology Development (ICETD 2017), (p. p. 758). Bandar Lampung.

Sugiyono. (2014). Metode Penelitian Kuantitatif Kualitatif dan $R \& D$. Alfabeta. 